\title{
Biological potential and GC-MS analysis of phytochemicals of Farsetia hamiltonii (Royle)
}

\author{
Muhammad Munawar Hayat*, Muhammad Uzair \\ Faculty of Pharmacy, Department of Pharmaceutical Chemistry, Bahauddin Zakariya University, Multan, Pakistan
}

\begin{abstract}
Objective: The study was designed to evaluate the biological and phytochemical potential of Farsetia hamiltonii (Royle), a desert medicinal plant belongs to family Brassicaceae and is traditionally used by residents of Cholistan to treat diabetic, different infectious diseases and gastrointestinal problems.

Method: Different biological/enzyme inhibition activities of crude extract of Farsetia hamiltonii were performed first time in this study. The dichloromethane and methanol extracts of aerial part of Farsetia hamiltonii were studied for anti-alphaglucosidase, anti-chymotrypsin, anti-urease, antibutyrylcholinesterase and anti-bacterial activities. The plant was explored first time regarding phytochemical constituents by using the GC-MS technique.

Results: The results of crude extracts of Farsetia hamiltonii were significant and provide justification for the traditional therapeutic potential in treating the diabetes, infectious diseases and gastrointestinal problems. Nine (9) compounds were identified by GC-MS technique.
\end{abstract}

Keywords: Anti-bacterial activity, Anti-chymotrypsin, Anti-alphaglucosidase, Farsetia hamiltonii royle.

Accepted May 18, 2019

\section{Introduction}

Cholistan desert is situated in south west of Punjab (Pakistan) and its area is about $26000 \mathrm{Km} 2$ having highly saline soil [1]. It is unique wild land having endemic flora containing 28 families and 138 species out of which about 64 species have been identified as medicinal plants [2]. The plants are traditionally used by inhabitants to treat different types of ailments as well as for animals by forming decoction, pellets and powder of herbs [3].

Farsetia hamiltonii (Royle) is a desert plant and is endemic to the desert area of Pakistan and India. It is an annual shrubby, often woody at base, 10-40 cm long, vary variable in size, densely appressed white hairs, braches erect or sub spreading, leaves oblong linear, thick woody roots, fruit a little longer, narrowed at either end, are distinctive. Flowers are white or pink in color, petals slightly longer than sepals and flowering season is March to September [4]. The medicinal use of plant is to treat pain, inflammation and swelling in joints, diabetes, gastrointestinal and infectious diseases. This plant is used with "Ghee" as a cooling medicine and tonic. Its boiled juice is applied to treat camel wound in Cholistan [3]. The local name is "Fareed Booti" [5]. This plant is selected for study keeping in view the medicinal importance of genus Farsetia. The ethyl alcohol extract of aerial parts of $F$. aegyptia was in vitro investigated for cytotoxicity and exhibited cytotoxicity against A549 and HepG2 carcinomas. The phenolic rich fraction was further fractionized and isolated a new flavonoid kampferol-8-C-O- $\beta$-diglucopyranoside which showed the high cytotoxicity against Hela and MCF-7 cell lines [6]. The alcoholic extract of $F$. aegyptia is evaluated for anti-bacterial and anti-fungal activities which show maximum inhibition against Klebsiella pneumonia and no activity against Candida albicans [7]. According to literature survey, no phytochemical and biological activities on $F$. hamiltonii have been reported and this species is found unexplored.

\section{Methods}

\section{Enzymes, chemicals and equipments}

Alpha glucosidase (EC 3.2.1.20), chymotrypsin (EC 3.4.21.1), urease (EC 3.5.1.5), Butyryl cholinesterase (EC 3.1.1.8), Acarbose, Chymostatin, Thiourea, Eserine, chloroform, acetone, diethyl ether, dichloromethane and methanol were purchased from Sigma-Aldrich and Merck companies. Ciprofloxacin, KH2PO4, DTNB [5,5-dithiobis (2-nitrobenzoic acid)], phosphate buffer, N-succinyl phenylalanine-P-nitroanilide and 4-nitrophenyl acetate were of analytical grade.

The gram-positive bacteria (Bacillus subtilis, Staphylococcus aureus) and gram-negative (Escherichia coli, Pseudomonas aeruginosa, Salmonella typhi) were used in this study.

The instruments synergy HT BioTek 96 microplate reader, Rotary evaporator (Buchi), Vacuum pump, Spectrophotometer (Shimadzo, Japan), EZ-Fit Enzyme Kinetics software (Perrella Scientific Inc. Amherst, USA) and Gas chromatography-mass spectrometry (GC Agilent system, USA) were used. 


\section{Plant collection and extraction}

The fresh plants of $F$. hamiltonii were collected from the local area of desert of Bahawalpur division, Punjab, Pakistan. The plant specimen was identified by research officer/ taxonomist, Mr. Hafiz Muhammad Waris from Cholistan Institute of Desert Studies (CIDS), The Islamia University of Bahawalpur, Pakistan. The plant specimen is deposited in the herbarium of CIDS for future reference and allocated voucher number 3470/CIDS/IUB.

The aerial parts of plants were dried under shade for 15 days and ground in fine powder by the mill. The powdered plant material of aerial parts of $F$. hamiltonii $(900 \mathrm{~g})$ were macerated in dichloromethane (4.5 liters) for 24 hours, the process was repeated for three days and then same in methanol for three days. The dichloromethane and methanol extracts are concentrated in solid residue by using the rotary evaporator under reduced pressure. The extracts were abbreviated as FHAD for dichloromethane extract of aerial parts of $F$. hamiltonii and FHAM for methanol extract of aerial parts of $F$. hamiltonii. The yields of extraction are $1.8 \%$ and $2.8 \%$ respectively.

\section{Biological and enzymatic activities}

Alpha glucosidase inhibition activity: This assay was performed according to the slightly modified method [8]. The $70 \mu \mathrm{L}$ phosphate buffer $(50 \mathrm{mM}, \mathrm{pH} 6.8), 10 \mu$ of plant extract solution $(0.5 \mathrm{mg} / \mathrm{ml})$, then, added $10 \mu \mathrm{l}$ alpha glucosidase enzyme ( 0.057 units). The contents were mixed and pre-read. The reaction was initiated by the addition of $10 \mu 1$ of $0.5 \mathrm{mM}$ per well substrate. The absorbance was measured at $400 \mathrm{~nm}$. Acarbose was used as standard. The results are given in Table 1.

Chymotripsin inhibition activity: A standard procedure was followed with slight modification [9]. $60 \mu \mathrm{l}$ Tris- $\mathrm{HCl}$ buffer $(50 \mathrm{mM}, \mathrm{pH} 7.6), 10 \mu \mathrm{l}$ plant extract solution $(0.5 \mathrm{mg} / \mathrm{ml})$ and $15 \mu \mathrm{l}$ purified $\alpha$-chymotrypsin enzyme ( 0.9 units) were mixed in 96-microwell plate. The contents were pre-read. The reaction was initiated by the addition of $15 \mu \mathrm{N}$-succinyl phenyl-alanine-p-nitroanilide $(1.3 \mathrm{mM})$. The absorbance was measured at $410 \mathrm{~nm}$. Chymostatin $(0.5 \mathrm{mM})$ was used as standard (Table 1).

Urease inhibition activity: It is the modified form of Berthelot activity [10]. The phosphate buffer $(10 \mu 1, \mathrm{pH}$ 7.0), $10 \mu \mathrm{l}$ of plant extract solution $(0.5 \mathrm{mg} / \mathrm{ml})$ and $25 \mu \mathrm{l}$ of urease enzyme solution ( 0.1347 units) were used. Then, $40 \mu \mathrm{l}$ of urea stock solution $(20 \mathrm{mM})$ was added and 115 $\mu \mathrm{l}$ phenol hypochlorite reagents (prepared by mixing $45 \mu \mathrm{l}$ phenol reagents with $70 \mu \mathrm{l}$ of alkali reagent) were added. The absorbance was measured at $625 \mathrm{~nm}$ and Kojic acid was used as standard (Table 1).

Butyrylcholinesterase inhibition activity: Butyryl cholinesterase (BChE) inhibition activity was performed according to the method [11]. In this assay, $60 \mu 1 \mathrm{KH} 2 \mathrm{PO} 4$ buffer $(100 \mathrm{mM}, \mathrm{pH} 7.7)$ and $10 \mu \mathrm{l}$ plant extract solution $(0.5 \mathrm{mg} / \mathrm{ml})$ were mixed, followed by the addition of $10 \mu \mathrm{l}$ enzyme butyryl cholinesterase. The contents were pre-read. The reaction was initiated by the addition of $10 \mu 1$ of DTNB. The absorbance was measured at $405 \mathrm{~nm}$ and Eserine was used as standard (Table 1).

Anti-bacterial activity: The method [12] was used, two grampositive bacteria (Bacillus subtilis, Staphylococcus aureus) and three gram-negative (Escherichia coli, Pseudomonas aeruginosa, Salmonella typhi) were included. The absorbance was measured at $540 \mathrm{~nm}$, before and after incubation and the difference was noted as an index of bacterial growth. Ciprofloxacin $(0.5 \mathrm{mM})$ was used as a standard. The percent inhibition was calculated using the formula:

Inhibition $(\%)=100 \times(\mathrm{X}-\mathrm{Y}) / \mathrm{X}$

Where $\mathrm{X}$ is absorbance in control with bacterial culture and $\mathrm{Y}$ is absorbance in test sample (plant extract solution). The results are given in Table 2.

Gas chromatography-mass spectrometry (GC-MS): GCMS analysis is used for identification of chemical constituents present in the sample. It has great importance in drug detection and identification of unknown phytochemical constituents present in the medicinal plants. So, GC-MS analysis included in the study to investigate the unknown constituents of the selected medicinal plants $F$. hamiltonii [13].

GC-MS analysis was performed on GC Agilent system (B 7890) with mass spectrometer detector (MSD-5977A) employing the following condition: Column HP-5MS, size $30 \mathrm{~m} \times 0.25 \mathrm{~mm}, 0.25 \mu$, composed of $100 \%$ dimethyl poly siloxane. The source temperature for ionization was set at $250^{\circ} \mathrm{C}$. The $2 \mu \mathrm{l}$ of dichloromethane and methanol extracts of aerial parts of $F$. hamiltonii were used in GC-MS analysis [14].

Table 1. Enzyme inhibition assay of dichloromethane and methanol extracts of Farsetia hamiltonii (Royle).

\begin{tabular}{|c|c|c|c|c|c|c|}
\hline \multirow[b]{2}{*}{ Enzyme Assay } & \multicolumn{2}{|c|}{ DCM $^{*}$ Extract } & \multicolumn{2}{|c|}{ Methanol Extract } & \multirow{2}{*}{$\begin{array}{c}\text { Standard } \\
\text { Inhibition (\%) }\end{array}$} & \multirow[b]{2}{*}{ IC50 ( $\mu$ moles $)$} \\
\hline & $\begin{array}{c}\text { Inhibition } \\
(\%)\end{array}$ & $\begin{array}{c}\text { IC50 } \\
(\mu \text { moles })\end{array}$ & $\begin{array}{c}\text { Inhibition } \\
(\%)\end{array}$ & $\begin{array}{c}\text { IC50 } \\
(\mu \mathrm{moles})\end{array}$ & & \\
\hline$\alpha$-glucosidase inhibition assay & $35.51 \pm .83$ & Inactive & $97.54 \pm .39$ & $25.32 \pm .12$ & $92.23 \pm 0.14$ Acarbose & $\begin{array}{c}38.25 \pm 0.12 \\
\text { Acarbose }\end{array}$ \\
\hline Chymotrypsin inhibition assay & $69.64 \pm .01$ & $333.12 \pm .01$ & $76.93 \pm .01$ & 238.570 .01 & $93.50 \pm 0.91$ Chymostatin & $\begin{array}{c}8.24 \pm 0.11 \\
\text { Chymostatin }\end{array}$ \\
\hline Urease inhibition assay & $56.77 \pm .27$ & $381.50 \pm .52$ & $63.31 \pm .46$ & $351.60 \pm 0.54$ & $82.11 \pm 0.14$ Thiourea & $\begin{array}{l}22.04 \pm 0.12 \\
\text { Thiourea }\end{array}$ \\
\hline $\begin{array}{l}\text { Butyrylcholin-esterase inhibition } \\
\text { assay }\end{array}$ & $21.96 \pm .22$ & Inactive & $21.96 \pm .22$ & Inactive & $91.29 \pm 1.17$ Eserine & $\begin{array}{l}0.04 \pm 0.001 \\
\text { Eserine }\end{array}$ \\
\hline
\end{tabular}


The GC-MS results revealed the presence of nine (09) compounds in two different extracts of aerial part of $F$. hamiltonii. The name, molecular formula, molecular weight and structure of the compounds are given in Tables 3 and 4 with their pharmacological effects. The five (5) compounds are identified in dichloromethane extract whereas four (04) compounds are identified in methanol extract of aerial part of $F$. hamiltonii.

\section{Statistical analysis}

The percentage enzyme inhibition was calculated by the following formula:

Inhibition $(\%)=100 \quad($ Absorbance of test sample/Absorbance of control) $\times 100$.

IC50 values (concentration at which there is $50 \%$ in enzyme catalyzed reaction) compounds were calculated using EZ-Fit Enzyme Kinetics Software (Perrella Scientific Inc. Amherst, USA). For the determination of IC50 values, test solutions were assayed at various dilutions i.e., 0.5, 0.25, 0.125, 0.0625 $\mathrm{mg} / \mathrm{ml}$. All the results (Tables 1 and 2) are mean \pm SEM (standard error of mean) of triplicate values $(n=3)$.

\section{Results}

Farsetia hamiltonii (Royle) is endemic desert plant used by hakims and residents of Cholistan desert by forming decoction or in powder form to treat diabetes, infections, pain, inflammation and gastrointestinal diseases [3]. To confirm the traditional anti-diabetic use of $F$. hamiltonii, alpha glucosidase inhibition activity was evaluated. The methanol extract of aerial parts of $F$. hamiltonii possess (\%) inhibition $97.54 \pm 2.39$ with IC $50=25.32 \pm 0.12 \mu \mathrm{M}$, was more potent in crude form than standard Acarbose having $92.23 \pm 0.14$ with $\mathrm{IC} 50=38.25 \pm 0.12 \mu \mathrm{M}$, which indicates that this FHAM crude extract may have some anti-diabetic compounds. The alpha glucosidase enzyme catalysis the hydrolysis of disaccharides into glucose, inhibition of this enzyme can suppress the post prandial hyperglycemia and this inhibition will be useful invention for management of diabetes type II [15]. The presence of this activity only in

Table 2. Results of anti-bacterial activity with MIC50 of crude extracts of aerial parts of $F$. hamiltonii.

\begin{tabular}{ccccccc}
\hline Extract Code & Type & $\begin{array}{c}\text { Bacillus subtilis } \\
\text { (G+ve) }\end{array}$ & $\begin{array}{c}\text { Staphylococcus } \\
\text { aureus (G+ve) }\end{array}$ & $\begin{array}{c}\text { Pseudomonas } \\
\text { aeruginosa (G-ve) }\end{array}$ & $\begin{array}{c}\text { Salmonella } \\
\text { typhi (G-ve) }\end{array}$ & $\begin{array}{c}\text { Escherichia } \\
\text { coli (G-ve) }\end{array}$ \\
\hline DCM Extract & Inhibition $^{*}(\%)$ & $65.17 \pm 4.28$ & $60.17 \pm 4.28$ & $74.02 \pm 1.39$ & $74.10 \pm 1.33$ & $68.64 \pm 1.36$ \\
(FHAD) & MIC50 & $13.93 \pm 0.84$ & $13.21 \pm 1.58$ & $9.69 \pm 1.90$ & $9.44 \pm 1.09$ & $12.69 \pm 0.37$ \\
Methanol Extract & Inhibition (\%) & $54.70 \pm 0.75$ & $56.33 \pm 1.50$ & $54.63 \pm 0.05$ & $58.13 \pm 1.46$ & $51.40 \pm 1.15$ \\
(FHAM) & MIC50 & $13.40 \pm 0.34$ & $12.70 \pm 0.33$ & $13.48 \pm 0.12$ & $12.37 \pm 0.12$ & $17.87 \pm 0.41$ \\
Ciprofloxacin & Inhibition (\%) & $91.23 \pm 1.07$ & $91.23 \pm 1.07$ & $90.88 \pm 0.16$ & $92.65 \pm 1.10$ & $91.45 \pm 2.19$ \\
(standard) & MIC50 & $7.52 \pm 0.67$ & $7.03 \pm 0.53$ & $7.58 \pm 0.19$ & $7.23 \pm 0.71$ & $8.21 \pm 0.11$ \\
\hline
\end{tabular}

${ }^{*}$ Concentration of extract was $100 \mu \mathrm{g} /$ well

Table 3. Phytochemical constituents identified by GC-MS in dichloromethane extract of aerial part of Farsetia hamiltonii Royle.

\begin{tabular}{|c|c|c|c|c|c|c|}
\hline $\begin{array}{r}\text { S. } \\
\text { No. }\end{array}$ & $\begin{array}{l}\text { Phytochemical } \\
\text { compound }\end{array}$ & $\mathrm{RT}$ (min) & $\begin{array}{c}\text { Mol. } \\
\text { formula }\end{array}$ & Mol. weight & Structure & Pharmacological effect \\
\hline 1 & $\begin{array}{l}\text { 12-methyl-E,E- } \\
\text { 2,13-octadecadien- } \\
\text { 1-ol }\end{array}$ & 12.55 & $\mathrm{C}_{9} \mathrm{H}_{36} \mathrm{O}$ & 280 & & $\begin{array}{c}\text { Anti-microbial and anti-fungal agent, Already } \\
\text { identified in plant Gossypium saeed and T. } \\
\text { hemprichii [17]. }\end{array}$ \\
\hline 2 & $\begin{array}{l}\text { Estra-1,3,5(10)- } \\
\text { trien-17 } \beta \text {-ol }\end{array}$ & 13.42 & $\mathrm{C}_{8} \mathrm{H}_{24} \mathrm{O}$ & 256 & & $\begin{array}{l}\text { Anti-proliferative effect for treatment of primary } \\
\text { breast cancer [18]. }\end{array}$ \\
\hline 3 & Oleic acid & 14.36 & $\mathrm{C}_{18} \mathrm{H}_{34} \mathrm{O} 2$ & 282 & & $\begin{array}{l}\text { Deficiency case the acne and skin problems, anti- } \\
\text { oxidant, reduce blood pressure, prevents ulcerative } \\
\text { colitis [19], Already identified in plant Euphorbia } \\
\text { hirta Linn [24]. }\end{array}$ \\
\hline 4 & $\begin{array}{l}\text { 13-Heptadecyn- } \\
\text { 1-ol }\end{array}$ & 14.53 & $\mathrm{C}_{17} \mathrm{H}_{32} \mathrm{O}$ & 252 & & $\begin{array}{l}\text { Anti-inflammatory and anti-fungal activity, } \\
\text { Already identified in plant Sinapis arvensis [20] } \\
\text { and Euphorbia hirta Linn [24]. }\end{array}$ \\
\hline 5 & $\begin{array}{l}\text { Ethyl iso- } \\
\text { allocholate }\end{array}$ & 17.13 & $\mathrm{C}_{26} \mathrm{H}_{44} \mathrm{O}_{5}$ & 436 & & $\begin{array}{c}\text { Anti-bacterial agent, Inhibitor of dihydropteroate } \\
\text { synthetase enzyme, Already identified in from } \\
\text { medicinal rice Karungkavuni [21]. }\end{array}$ \\
\hline
\end{tabular}


Table 4. Phytochemical constituents identified by GC-MS in methanol extract of aerial part of Farsetia hamiltonii Royle.

\begin{tabular}{|c|c|c|c|c|c|c|}
\hline $\begin{array}{l}\text { S. } \\
\text { No }\end{array}$ & $\begin{array}{c}\text { Phytochemical } \\
\text { compound }\end{array}$ & $\begin{array}{c}\text { RT } \\
(\mathrm{min})\end{array}$ & $\begin{array}{c}\text { Mol. } \\
\text { formula }\end{array}$ & $\begin{array}{l}\text { Mol } \\
\text { wt. }\end{array}$ & Structure & $\begin{array}{c}\text { Pharmacological } \\
\text { effect }\end{array}$ \\
\hline 1 & Octadecan, 6-methyl & 6.17 & $\mathrm{C}_{19} \mathrm{H}_{40}$ & 268 & & $\begin{array}{l}\text { Not found from } \\
\text { literature. }\end{array}$ \\
\hline 2 & $\begin{array}{l}\text { Cyclo propane } \\
\text { botanic acid, } \\
2-[[2-[[2-[(2-\text { pentyl } \\
\text { cyclo propyl)methyl] } \\
\text { cyclo propyl] } \\
\text { methyl] cyclo propyl] } \\
\text { methyl]-methyl ester }\end{array}$ & 13.17 & $\mathrm{C}_{25} \mathrm{H}_{42} \mathrm{O}_{2}$ & 374 & & $\begin{array}{l}\text { Already identified } \\
\text { in Wrightia tinctoria } \\
\text { seed [22]. }\end{array}$ \\
\hline 3 & $\begin{array}{l}\text { Hexadecanoic acid, } \\
\text { methyl ester }\end{array}$ & 14.29 & $\mathrm{C}_{7} \mathrm{H}_{34} \mathrm{O}_{2}$ & 270 & & $\begin{array}{l}\text { Anti-oxidant, } \\
\text { Hypocholesterolemic } \\
\text { effect, Nematicide, } \\
\text { Pesticide, anti- } \\
\text { androgenic, } \\
\text { Hemolytic, 5-alpha } \\
\text { reductase inhibitor } \\
\text { [23], Already } \\
\text { identified in Fluggea } \\
\text { leucopyrus and } \\
\text { Gossypium seeds } \\
\text { 17]. }\end{array}$ \\
\hline 4 & Ethyl iso-allocholate & 14.37 & $\mathrm{C} 26 \mathrm{H} 44 \mathrm{O} 5$ & 436 & & $\begin{array}{l}\text { Anti-microbial } \\
\text { activity, Already } \\
\text { identified in from } \\
\text { medicinal rice } \\
\text { Karungkavuni [21]. }\end{array}$ \\
\hline
\end{tabular}

methanol extract indicates that some polar biomolecules are responsible for anti-diabetic effect. The results are shown in Table 1.

Traditional practitioners use the plant $F$. hamiltonii to treat gastrointestinal problems and other illnesses. The enzyme inhibition studies for different enzymes (chymotrypsin, urease and butyryl cholinesterase) for both dichloromethane and methanol extracts of $F$. hamiltonii were performed in triplicate and presented with SEM in Table 1. The dichloromethane extract possess significant inhibition of chymotrypsin (69.64 $\pm 0.01 \%$ with IC50 value $=333.12 \pm 0.01 \mu \mathrm{M})$ and urease $(56.77 \pm 0.27 \%$ with IC50 value $=381.50 \pm 0.52 \mu \mathrm{M})$ activities, whereas methanol extracts exhibited chymotrypsin inhibition $(76.93 \pm 0.01 \%$ with IC50 value $=238.57 \pm 0.01 \mu \mathrm{M})$ and urease inhibition $(63.31 \pm 0.46 \%$ with IC50 value $=351.60 \pm$ $0.54 \mu \mathrm{M})$ activities.

Research is going on enzyme urease regarding its correlation with several diseases including in animals and humans like urinary tract diseases and gastro duodenal diseases. An important role played in the pathogenesis of a disease by the bacterial urease including bacterial species like Staphylococcus saprophiticus, Ureaplasma urealiticum, Yesinia enterocolitica and Proteus mirabilis [16]. Both extracts (FHAD and FHAM) of the plant not exhibited the anti-butyryl cholinesterase activity.

The anti-bacterial activity of both dichloromethane and methanol extracts was evaluated concentration (20 $\mu \mathrm{g} / \mathrm{ml}$ ) against two gram-positive bacteria (Bacillus subtilis, Staphylococcus aureus) and three gram-negative (Pseudomonas aeruginosa, Salmonella typhi, Escherichia coli). The percentage inhibition and MIC50 values (Table 2) shows that both dichloromethane and methanol extracts (FHAD and FHAM) has significant bacterial growth percentage inhibition and MIC50 values are very well comparable with standard ciprofloxacin. The bacterial growth inhibition ranging from $54-74 \%$ which is indicating the potential of crude extracts of Farsetia hamiltonii regarding presence of anti-bacterial biomolecules.

To identify the chemical constituents in the two crude extracts of $F$. hamiltonii, the GC-MS technique was used in the study. The five (5) compounds were identified in the dichloromethane extract (FHAD), whereas four (4) compounds were identified in methanol extract (FHAM) of aerial part of $F$. hamiltonii (Tables 3 and 4) [17-24].

The names of nine (9) identified compounds are: (1) 12-methyl-E,E-2,13-octadecadien-1-ol, (2) estra-1,3,5(10)- 


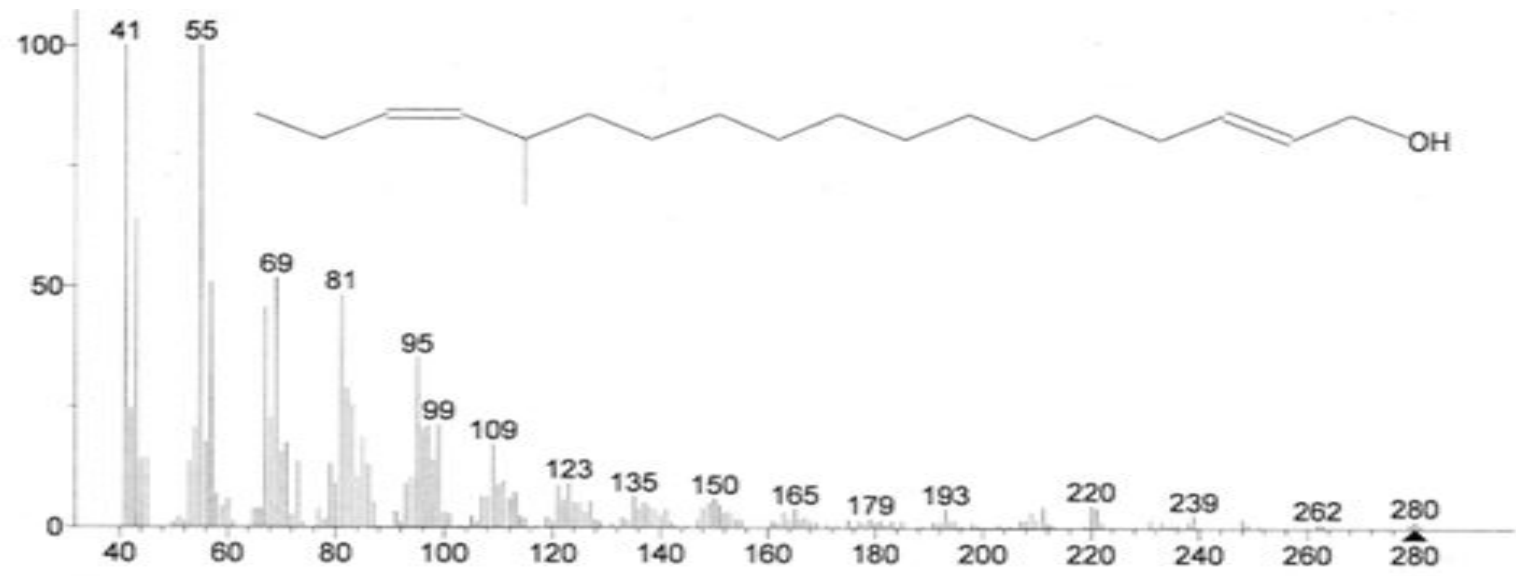

(mainlib) 12-Methyl-E,E-2,13-octadecadien-1-ol

Name: 12-Methyl-E,E-2,13-octadecadien-1-ol Formula: $\mathrm{C}_{19} \mathrm{H}_{36} \mathrm{O}$

MW: 280 Exact Mass: 280.276615 NIST\#: 130904 ID\#: 17778 DB: mainlib Contributor: J. Klune, Insect Chem. Ecol. Lab., USDA, Beltsville, MD 20705

Figure 1. Mass spectra and structure of 12-methyl-E,E-2,13-octadecadien-1-ol.

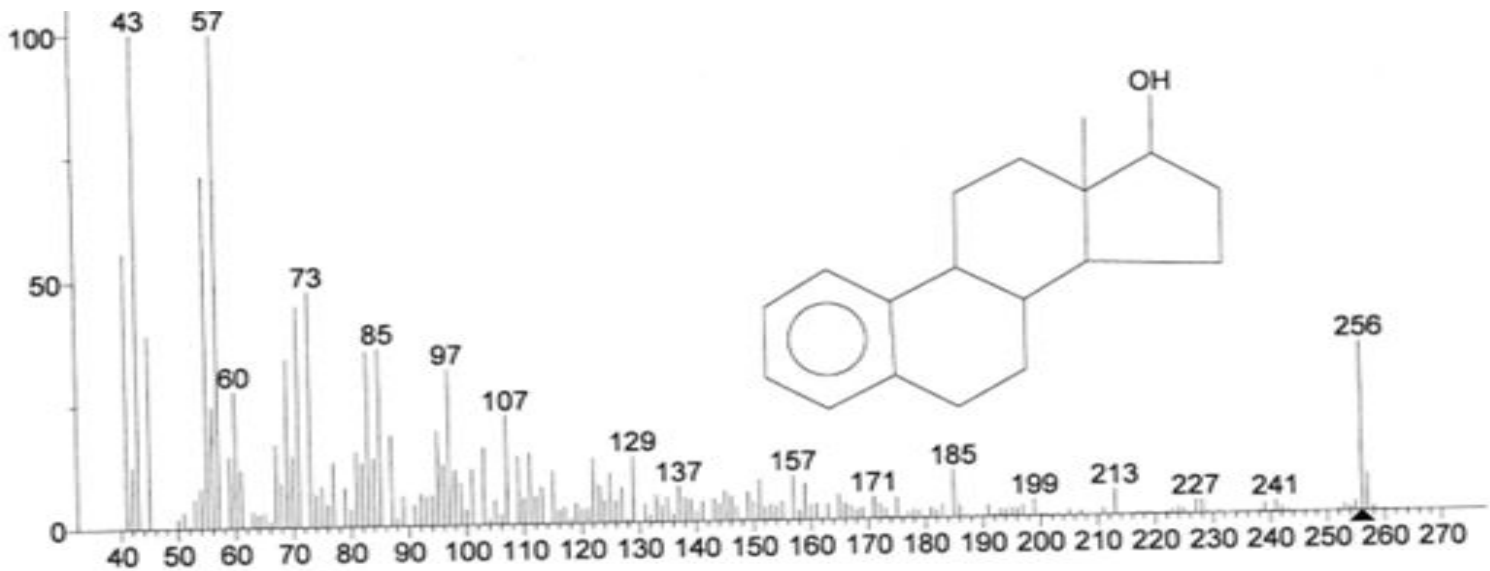
(mainlib) Estra-1,3,5(10)-trien-17 $\beta$-ol

Name: Estra-1,3,5(10)-trien-17ß-ol

Formula: $\mathrm{C}_{18} \mathrm{H}_{24} \mathrm{O}$

MW: 256 Exact Mass: 256.182714 CAS\#: 2529-64-8 NIST\#: 254855 ID\#: 7345 DB: mainlib

Figure 2. Mass spectra and structure of estra-1,3,5(10)-trien-17 $\beta$-ol.

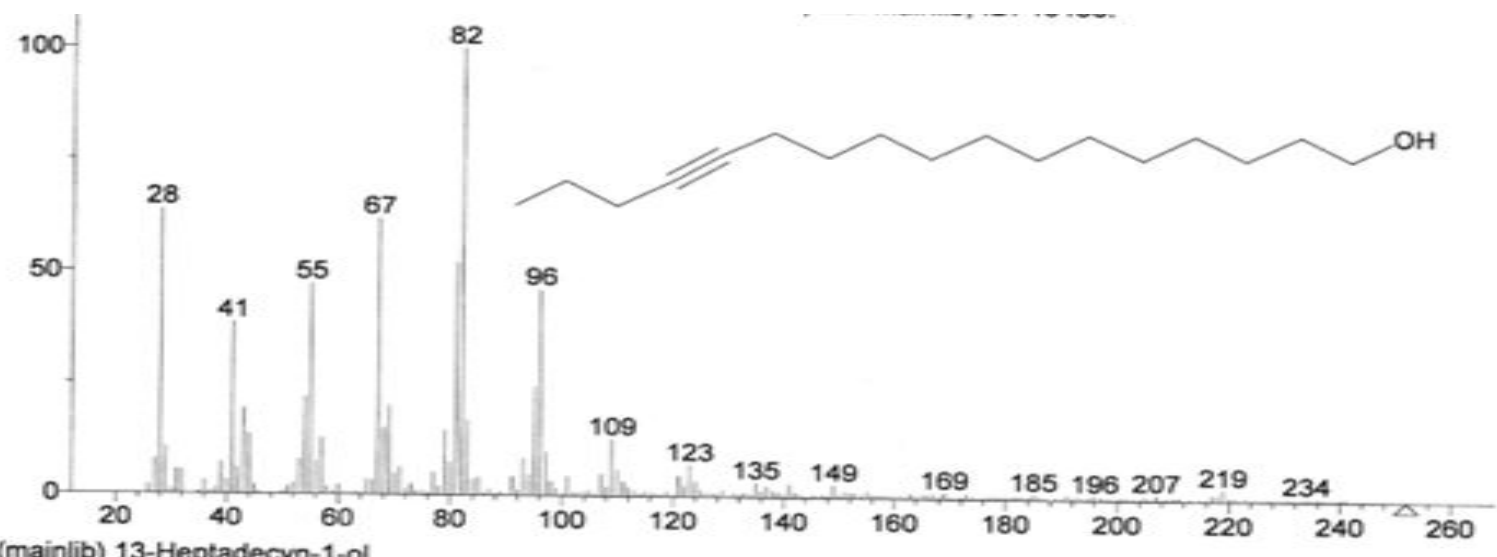

(mainlib) 13-Heptadecyn-1-ol

Name: 13-Heptadecyn-1-ol

Formula: $\mathrm{C}_{17} \mathrm{H}_{32} \mathrm{O}$

MW: 252 Exact Mass: 252.245316 CAS\#: 56554-77-9 NIST\#: 36374 ID\#: 46436 DB: mainlib

Figure 3. Mass spectra and structure of oleic acid. 
Biological potential and GC-MS analysis of phytochemicals of Farsetia hamiltonii (Royle).

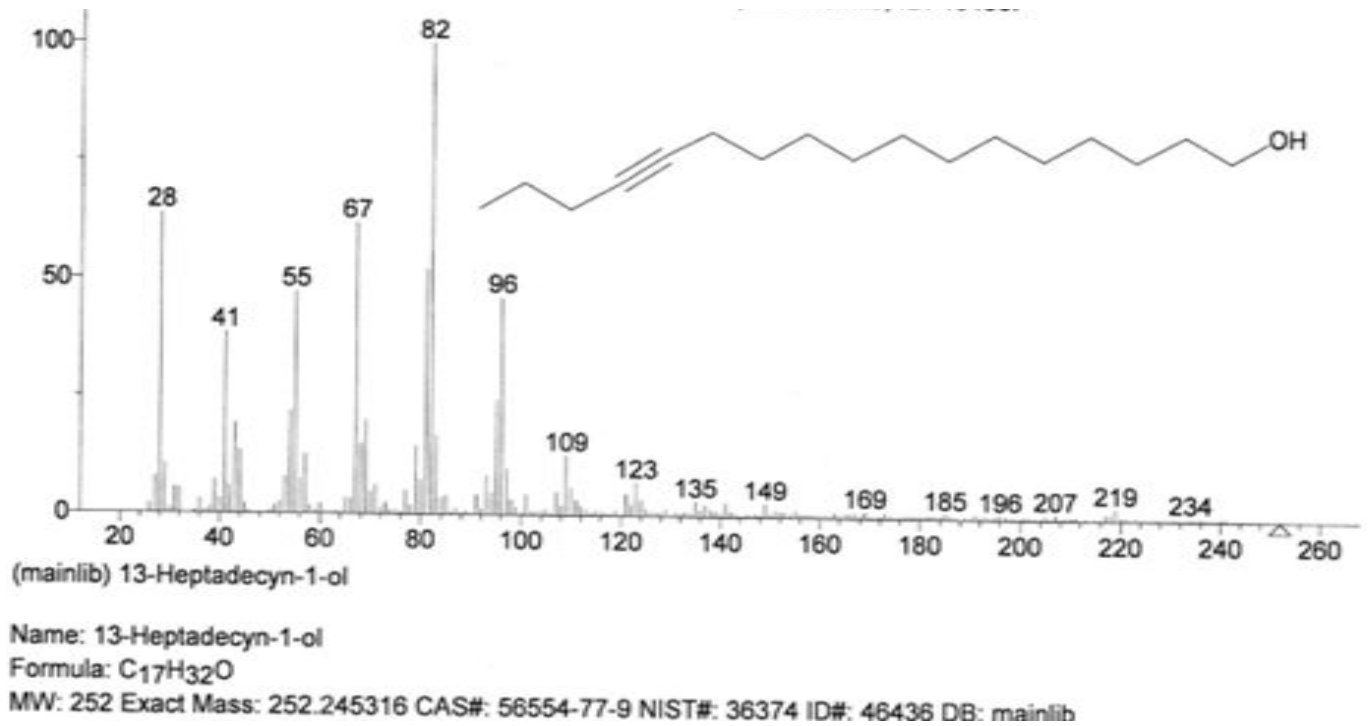

Figure 4. Mass spectra and structure of 13-heptadecyn-1-ol.

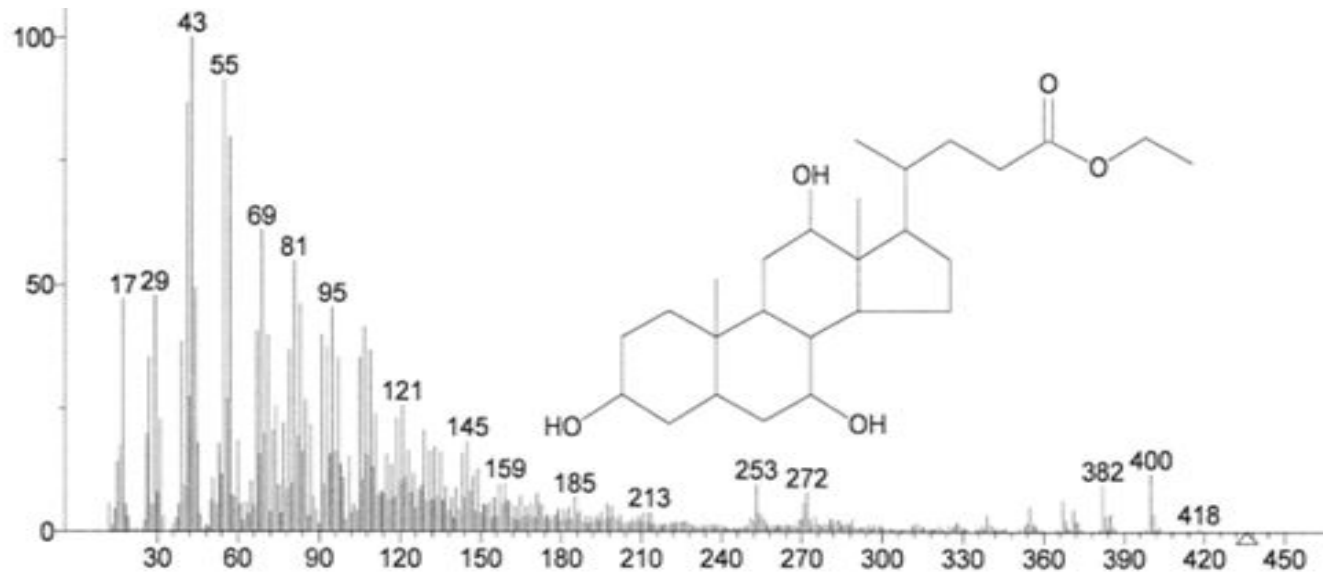

(mainlib) Ethyl iso-allocholate

Name: Ethyl iso-allocholate

Formula: $\mathrm{C}_{26} \mathrm{H}_{44} \mathrm{O}_{5}$

MW: 436 Exact Mass: 436.318874 NIST\#: 43053 ID\#: 6654 DB: mainlib

Contributor: R RYHAGE MS-LAB KAROLINSKA INSTITUTET STOCKHOLM SWEDEN

Figure 5. Mass spectra and structure of ethyl iso-allocholate.

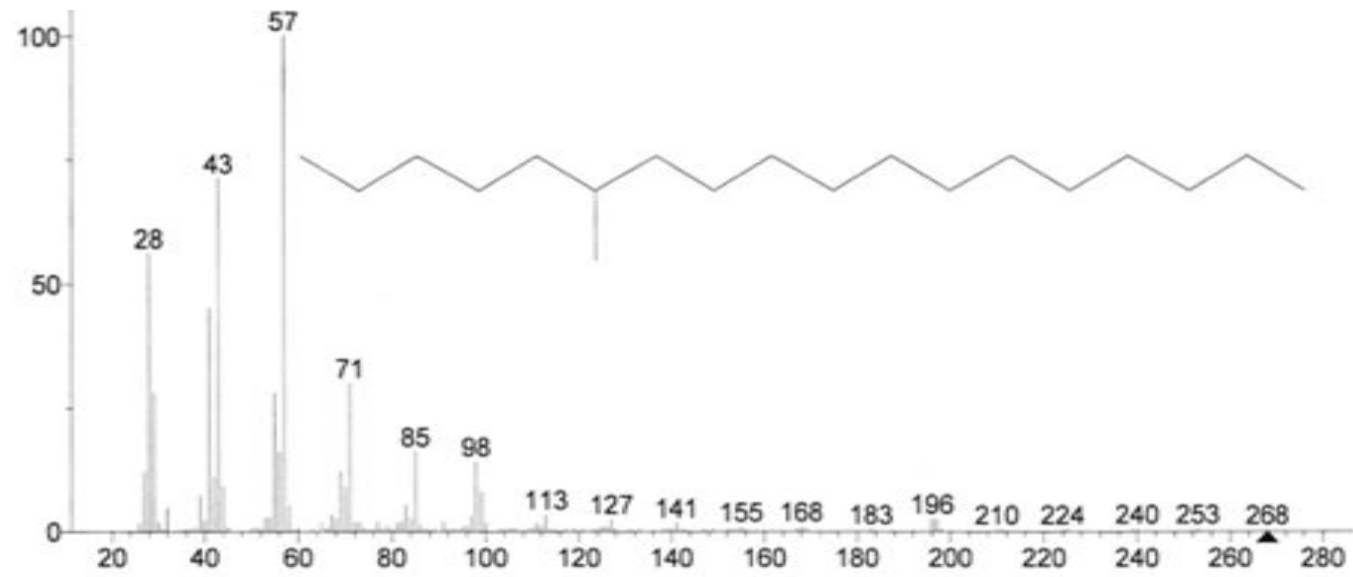

(mainlib) Octadecane, 6-methyl-

Name: Octadecane, 6-methyl-

Formula: $\mathrm{C}_{19} \mathrm{H}_{40}$

MW: 268 Exact Mass: 268.313002 CAS\#: 10544-96-4 NIST\#: 35803 ID\#: 22294 DB: mainlib

Figure 6. Mass spectra and structure of octadecan, 6-methyl. 


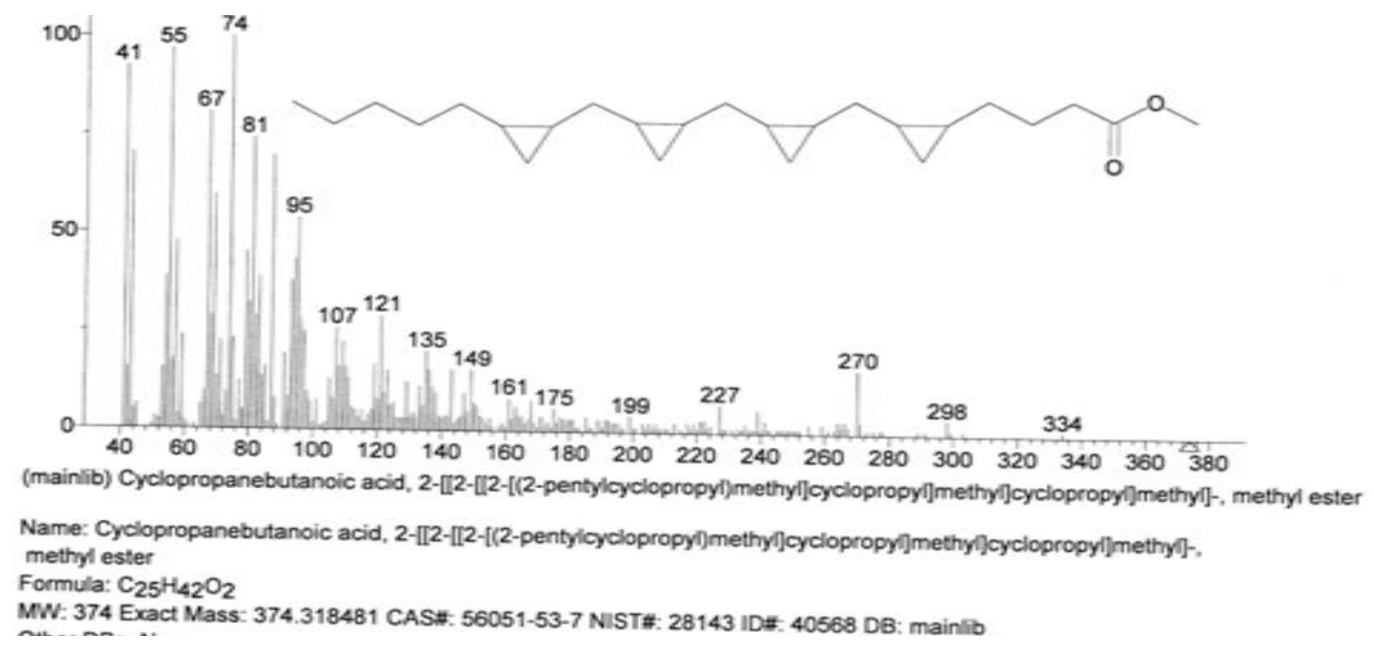

Figure 7. Mass spectra and structure of cyclo propane botanic acid, 2-[[2-[[2-[(2-pentyl cyclo propyl)methyl] cyclo propyl]methyl]cyclo propyl]methyl]-, methyl ester.

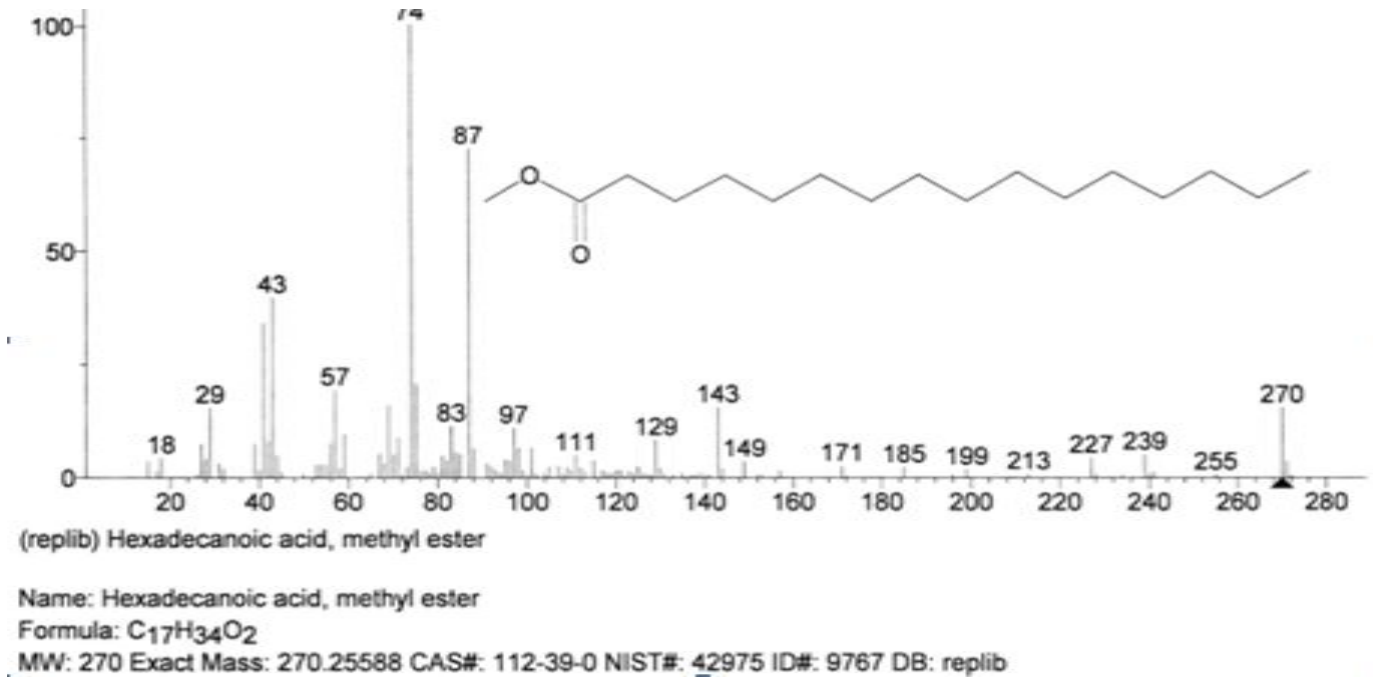

Figure 8. Mass spectra and structure of hexadecanoic acid, methyl ester.

trien-17ß-ol,(3)oleic acid, (4) 13-heptadecyn-1-ol, (5) ethyl isoallocholate, (6) octadecan, 6-methyl-(7) cyclo propane botanic acid, 2-[[2-[[2-[(2-pentyl cyclo propyl) methyl] cyclo propyl] methyl]cyclo propyl]methyl]-, methyl ester (8) hexadecanoic acid, methyl ester and (9) ethyl iso-allocholate were identified by performing the analysis of two extracts (FHAD, FHAM) of aerial part of $F$. hamiltonii by GC-MS technique, whereas the ethyl iso-allocholate (Compounds 5 and 9) was identified in both extracts. The Mass spectra of identified compounds are given in Figures 1 to 8. The pharmacological effects or uses of these nine identified compounds are reported in the literature and having anti-microbial, anti-fungal, anti-proliferative, antioxidant and anti-inflammatory potentials.

\section{Conclusion}

The results of the study validated the folkloric uses of plant Farsetia hamiltonii regarding its pontential of antialphaglucosidase, anti-chymotrypsin, anti-urease and antibacterial activities. Best of our knowledge, this is the first study on biological activities of crude extracts of Farsetia hamiltonii provides rational hypothesis for medicinal use of aerial parts of $F$. hamiltonii to treat diabetes, infectious diseases and gastrointestinal problems. The methanol extract of aerial part of Farsetia hamiltonii (Royle) exhibited very strong alpha glucosidase inhibition proving its hypoglycemic use. Further, the potential of nine (09) identified phytochemical constituents from the aerial part of Farsetia hamiltonii (Royle) is very importantly reported in literature having antimicrobial, anti-fungal, anti-proliferative, anti-oxidant, antiinflammatory activities.

\section{Acknowledgments}

The authors are grateful to Mr. Zafar Mehmood, Depatment of Statistics, and the Islamia University of Bahawalpur, Bahawalpur Pakistan regarding help in statistical calculations.

\section{Conflict of Interest}

No conflict of interest associated with this study.

\section{Author's Contribution}

It is declare that this work was done by the authors named in this article and all liabilities pertaining to claims relating to the content of this article will be borne by them. 


\section{References}

1. Arshad M, Ashraf MY, Ahmad M, Zaman F. Morpho-genetic variability potential of Cenchrusciliaris L. from Cholistan desert, Pakistan. Pak J Bot 2007; 39: 1481-1488.

2. Ahmad S, Alam K, Waris HM, Anjum S, Mukhtar M. Ethnobotanical studies of plant resources of Cholistan desert, Pakistan. Int J Sci Res 2014; 3: 1782.

3. Arshad M, Akbar G, Rashid S. Wealth of medicinal plants of Cholistan desert, Pakistan. Hamdard Medicus 2002;XLV: 25-34.

4. Nasir E, Ali SI, The Flora of West Pakistan, An annotated catalogue of the vascular plants of West Pakistan and Kashmir 1972. Fakhri Printing Press, Karachi, Pakistan.

5. Bhandari MM, Flora of the Indian desert 1995. MPS reports, 39 BGKT extension, new pali road, Jodhpur.

6. El-Sharkawy E, Azza AM, Emad MA. Cytotoxity of new flavonoid compound isolated from Farsetia aegyptia. Int $\mathrm{J}$ Pharm Sci Inven 2013; 2: 23-27.

7. Atta EM, Hashem AI, El-Sharkawy ER. A novel flavonoid compound from Farsetia aegyptia and its anti-microbial activity. Chem Nat Comp 2013; 49:432-436.

8. Pierre C, Roland RT. $\rho$-Nitrophenol- $\alpha$-D-glucopyranoside as substrate for measurement of maltase activity in human semen. Clinical Chem 1978; 24: 208-211.

9. Rehman AU, Iqbal M, William J. Manual of bioassay techniques for natural product research 1999. Harwood academic Publishers, Amsterdam.

10. Lois MB, Ronald LS. Application of the Berthelot reaction for rapid detection of urea hydrolysis by proteus strains. J Bacteriol 1963; 85: 954.

11. Ellman GL, Courtney KD, Andres V, Featherstone RM. A new and rapid calorimetric determination of acetylcholinesterase activity. Biochem Pharmacol 1961; 7: 88-95.

12. Rehman AU, Iqbal M, William J. Bioassay techniques for drug development 2001. Harwood academic Publishers, France. pp. 14.

13. Sparkman OD, Zelda P, Fulton GK, Gas Chromatography and Mass Spectrometry: A Practical Guide; 2011.
14. Ronald AH. Development of Gas Chromatographic Mass Spectrometry. Anal Chem 2016; 88: 6955-6961.

15. Choudhary MI, Adhikari A, Rasheed S, Marasini BP, Hussain N, Kaleem WA, Rehman AU. Cyclopeptide alkaloids of Ziziphus oxyphylla Edgw, an novel inhibitors of alpha glucosidase enzyme and protein glycation. Phytochem Letters 2011; 4: 404406.

16. Mobely HL, Island MD, Hausinger RP. Molecular biology of microbial ureases. Microbiol Mol Biol Rev 1995; 59: 451-480.

17. Marimuthu K, Nandhini N, Ravi D. GC-MS analysis of phytochemicals, fatty acid profile, anti-microbial activity of Gossypium seeds. Int J Pharm Sci Rev Res 2014; 27: 273-276.

18. John FR, Nicholson RI, Bundred NJ, Anderson E, Rayter Z, Dowsett M, Fox JN, Gee JMW, Webster A, Wakeling AE, Morris C, Dixon M. Comparision of the short-term biological effects of 7- $\alpha$-[9-(4,4,5,5,5-pentafluropentylsulfinyl)-nonyl] estra-1,3,5,(10)-triene-3,17 $\beta$-diol (Faslodex) versus Tamoxifen in Postmenopausal women with primary Breast cancer. Cancer Research 2001

19. https;//mooscience.com/oleic-acid.html

20. Abeer FA, Kadhim MJ, Hameed IH. Determination of bioactive compounds of methanolic leaves extract of Sinapis arvensis using GC-MS. Int J Toxicol Pharmacol Res 2017; 9: 163-178.

21. Malathi K, Anbarasu A, Ramaiah S. Ethyl Iso-allocholate from medicinal rice Karungkavuni inhibits dihydropteroate synthetase in Escherichia coli: A molecular docking and dynamics study. Indian J Pharm Sci 2016; 78: 780-788.

22. Rajani S,Mukerjee A, Verma A. GC-MS analysis of Phytocomponents in Pet ether fraction of Wrightia tinctoria seed. PHCOG J 2015; 7: 249-253.

23. Sudha T, Chidambarampillai S, Mohan VR. GC-MS analysis of bioactive components of aerial parts of Fluggea leucopyrus Wild (Euphorbiaceae). J applied Pharm Sci 2013; 3: 126-130.

24. Modupe O, Okiei W, Ofor E, Osibote AE. Analysis of the essential oil of the dries leaves of Euphorbia hirta Linn (Euphorbiaceae), a potential medication for asthma. Afr $\mathrm{J}$ Biotechnol 2009; 8: 7042-7050.

\section{*Correspondence to}

Muhammad Munawar Hayat

Faculty of Pharmacy

Department of Pharmaceutical Chemistry

Bahauddin Zakariya University

Multan

Pakistan 